\title{
Supporting Information for Electronic Decay Constant of Carotenoid Polyenes from Single-Molecule Measurements
}

Jin $\mathrm{He}^{1}$, Fan Chen ${ }^{1}$, Jun Li ${ }^{1}$, Otto F. Sankey ${ }^{1}$, Yuichi Terazono ${ }^{2}$, Christian Herrero ${ }^{2}$, Devens Gust ${ }^{2}$, Thomas A. Moore ${ }^{2}$,

\author{
Ana L. Moore ${ }^{2}$ and Stuart M. Lindsay ${ }^{1,2,3}$ * \\ ${ }^{1}$ Department of Physics and Astronomy, ${ }^{2}$ Department of Chemistry and Biochemistry \\ and ${ }^{3}$ Biodesign Institute, Arizona State University, Tempe, AZ 85287, USA. \\ RECEIVED DATE (automatically inserted by publisher);Stuart.Lindsay@asu.edu
}

Synthesis of 5,7,9, and 11-Double Bond Carotenodithiols

Instrumental Techniques. The $1 \mathrm{H}$ NMR spectra were recorded on Varian spectrometers Gemini at $300 \mathrm{MHz}$ or Unity at $500 \mathrm{MHz}$. Mass spectra were obtained on a matrix-assisted laser desorption/ionization time-of-flight spectrometer (MALDI-TOF). Ultraviolet-visible spectra were measured on a Shimadzu UV2100U UV/vis spectrometer.

Synthesis. 4-Acetylthiomethylbenzyltriphenylphosphonium bromide1, 2,7-dimethylocta-2,4,6-triene-1,8-dial (12,12'diapocarotene-12,12'-dial)2,3, and crocetindial (8,8'diapocarotene-8,8'-dial)4 were synthesized by published methods. Triethyl phosphonoacetate was purchased from Aldrich. The structures of the compounds were verified by their mass spectra and the following 2D NMR experiments: COSY, HMQC, HMBC, and ROESY. HPLC (reversed phase) analyses indicated that the carotenedithiols after purification were stereoisomerically pure (all-trans).

11,11'-Bis(4-acetylthiomethylphenyl)-11,11'-diapocarotene (1a).

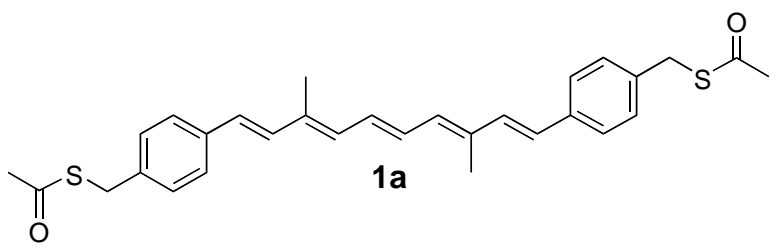

Portions of 2,7-dimethylocta-2,4,6-triene-1,8-dial (100 mg, $0.609 \mathrm{mmol})$, 4-acetylthiomethylbenzyltriphenylphosphonium bromide (672 mg, $1.52 \mathrm{mmol}$ ), and sodium hydride (60wt \% in mineral oil, $61 \mathrm{mg}, 2.3 \mathrm{mmol}$ ) were stirred in dry tetrahydrofuran (30 mL) under $\mathrm{N}_{2}$ at room temperature overnight. Chromatography (silica gel, dichloromethane/hexanes/acetone, 50/49/1) gave $172 \mathrm{mg}$ (58 \% yield) of 1a: ${ }^{1} \mathrm{H}$ NMR $(300 \mathrm{MHz}$, $\left.\mathrm{CDCl}_{3}\right) \delta 2.02\left(6 \mathrm{H}, \mathrm{s}, \mathrm{CH}_{3}\right.$ - at $\mathrm{C}^{13,13}$ ), 2.35 (6H, s, $\left.\mathrm{CH}_{3} \mathrm{CO}-\right), 4.11$ $\left(4 \mathrm{H}, \mathrm{s},-\mathrm{CH}_{2} \mathrm{~S}-\right), 6.36\left(2 \mathrm{H}, \mathrm{m}, H^{14,14}\right), 6.56(2 \mathrm{H}, \mathrm{d}, J=16 \mathrm{~Hz}$, $\left.H^{11,11^{\prime}}\right), 6.69\left(2 \mathrm{H}, \mathrm{dd}, J=8,3 \mathrm{~Hz}, H^{15,15^{\prime}}\right), 6.86(2 \mathrm{H}, \mathrm{d}, J=16 \mathrm{~Hz}$, $\left.H^{12,12}\right), 7.23(4 \mathrm{H}, \mathrm{d}, J=8 \mathrm{~Hz}$, Ar-ortho- $H), 7.36(4 \mathrm{H}, \mathrm{d}, J=8 \mathrm{~Hz}$, Ar-meta- $H$ ); MS (MALDI-TOF) $\mathrm{m} / \mathrm{z}: 488.177$ (calcd for $\mathrm{C}_{30} \mathrm{H}_{32} \mathrm{O}_{2} \mathrm{~S}_{2}$ : 488.184).
11,11'-Bis(4-thiomethylphenyl)-11,11'-diapocarotene (I).<smiles>CC(/C=C/c1ccc(CS)cc1)=C\C=C\C=C\c1ccc(CS)cc1</smiles>

Protected carotene 1a (50 mg, $0.10 \mathrm{mmol}$ ) was dissolved in 10 $\mathrm{mL}$ of a mixture of tetrahydrofuran /methanol (40/10) and $30 \%$ aqueous ammonia $(3 \mathrm{~mL}$ ) was added. The mixture was stirred under $\mathrm{N}_{2}$ at room temperature overnight. After being acidified with $5 \%$ aqueous L-ascorbic acid, the mixture was diluted with dichloromethane $(100 \mathrm{~mL})$ and washed with water. Flash column chromatography (silica gel, dichloromethane/hexanes, 70/30) gave $20 \mathrm{mg}$ (49 \%) of I: ${ }^{1} \mathrm{H}$ NMR (300 $\left.\mathrm{MHz}, \mathrm{CDCl}_{3}\right) \delta 1.76(2 \mathrm{H}$, t, $J=8 \mathrm{~Hz},-\mathrm{SH}), 2.04\left(6 \mathrm{H}, \mathrm{s}, \mathrm{CH}_{3}-\right.$ at $\left.\mathrm{C}^{13,13}\right), 3.74(4 \mathrm{H}, \mathrm{d}, J=8$ $\left.\mathrm{Hz},-\mathrm{CH}_{2} \mathrm{SH}\right), 6.37\left(2 \mathrm{H}, \mathrm{m}, H^{14,14}\right), 6.58(2 \mathrm{H}, \mathrm{d}, J=16 \mathrm{~Hz}$, $\left.H^{11,11^{\prime}}\right), 6.70\left(2 \mathrm{H}, \mathrm{dd}, J=8,3 \mathrm{~Hz}, H^{15,15}\right), 6.88(2 \mathrm{H}, \mathrm{d}, J=16 \mathrm{~Hz}$, $H^{12,12}$ ) $) 7.27$ (4H, d, $J=8 \mathrm{~Hz}$, Ar-ortho- $H$ ), 7.39 (4H, d, $J=8 \mathrm{~Hz}$, Ar-meta-H); MS (MALDI-TOF) $\mathrm{m} / \mathrm{z}$ : 404.157 (calcd for $\mathrm{C}_{26} \mathrm{H}_{28} \mathrm{~S}_{2}$ : 404.163); UV/vis (toluene) 397, 419, $445 \mathrm{~nm}$.

9,9'-Bis(4-acetylthiomethylphenyl)-9,9'-diapocarotene (2a).

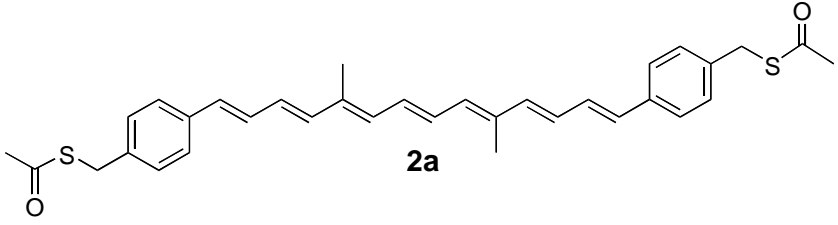

A portion of 10,10'-diapocarotene-10,10'-dial (5) (102 mg, $0.472 \mathrm{mmol})$, 4-acetylthiomethylbenzyltriphenylphosphonium bromide (604 mg, $1.16 \mathrm{mmol}$ ), and sodium hydride (60wt \% in mineral oil, $274 \mathrm{mg}, 6.85 \mathrm{mmol}$ ) were stirred in dry tetrahydrofuran $(30 \mathrm{~mL})$ under $\mathrm{N}_{2}$ at $45^{\circ} \mathrm{C}$ for $48 \mathrm{~h}$. The reaction was quenched with $0.5 \mathrm{M}$ citric acid at $0^{\circ} \mathrm{C}$ and the tetrahydrofuran was removed under vacuum. The residue was dissolved in dichloromethane and washed with $0.5 \mathrm{M}$ citric acid and water. After the dichloromethane was removed, the residue was chromatographed on a silica gel column (dichloromethane/hexanes, 70/30) to obtain a mixture of cis and trans-isomers. The mixture was dissolved in dichloromethane and adsorbed on a minimum amount of silica gel. After being dried 
completely, the mixture of the carotene isomers and silica gel was placed on the same volume of dry silica gel in a column and washed with hexane/acetone $(95 / 5)(750 \mathrm{~mL})$. The compounds remaining on the silica gel were extracted with dichloromethane/acetone (90/10) and the solvents were removed in vacuum, to yield an orange residue. After the residue was dissolved in dichloromethane, the pure $\left(9 E, 9 E^{\prime}\right)$ isomer was precipitated out by adding methanol to the solution. Filtration followed by vacuum drying of the precipitate gave $76 \mathrm{mg}$ (30\%) of 2a: ${ }^{1} \mathrm{H}$ NMR (300 MHz, $\left.\mathrm{CDCl}_{3}\right) \delta 1.97\left(6 \mathrm{H}, \mathrm{s}, \mathrm{CH}_{3}-\right.$ at $\left.\mathrm{C}^{13,13}\right)$, 2.35 (6H, s, $\left.\mathrm{CH}_{3} \mathrm{CO}-\right)$, $4.10\left(4 \mathrm{H}, \mathrm{s},-\mathrm{CH}_{2} \mathrm{~S}-\right), 6.28\left(2 \mathrm{H}, \mathrm{m}, \mathrm{H}^{14,14^{\prime}}\right)$, $6.45\left(2 \mathrm{H}, \mathrm{d}, J=3 \mathrm{~Hz}, H^{12,12^{\prime}}\right), 6.46\left(2 \mathrm{H}, \mathrm{d}, J=8 \mathrm{~Hz}, H^{11,11}\right), 6.56$ ( $\left.2 \mathrm{H}, \mathrm{d}, J=16 \mathrm{~Hz}, H^{9,9^{\prime}}\right), 6.65$ ( $\left.2 \mathrm{H}, \mathrm{dd}, J=8,3.0 \mathrm{~Hz}, H^{15,15^{\prime}}\right), 6.87$ (2H, ddd, $\left.J=36,8,3 \mathrm{~Hz}, H^{10,10^{\prime}}\right), 7.22(4 \mathrm{H}, \mathrm{d}, J=8 \mathrm{~Hz}$, Ar-meta$H$ ), 7.33 (4H, d, $J=8 \mathrm{~Hz}$, Ar-ortho- $H$ ); MS (MALDI-TOF) $m / z$ : 540.207 (calcd for $\mathrm{C}_{34} \mathrm{H}_{36} \mathrm{O}_{2} \mathrm{~S}_{2}$ : 540.216).

9,9'-Bis(4-thiomethylphenyl)-9,9'-diapocarotene (II).

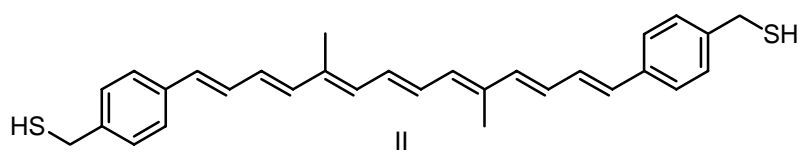

A $10 \%$ aqueous solution of $\mathrm{KOH}(2 \mathrm{~mL})$ was added to the solution of 2a (20 mg, $0.037 \mathrm{mmol})$ in pyridine/methanol (30/1, $20 \mathrm{~mL}$ ) and the mixture was stirred under $\mathrm{N}_{2}$ at room temperature for $48 \mathrm{~h}$. After the solution was acidified with $5 \%$ L-ascorbic acid, the solvents were removed by distillation under reduced pressure at room temperature. The residue was dissolved in dichloromethane, washed with $5 \%$ L-ascorbic acid and water, and chromatographed on a silica gel column (dichloromethan/hexanes, 70/30) to yield $6 \mathrm{mg}$ (36\%) of II: ${ }^{1} \mathrm{H}$ NMR $\left(300 \mathrm{MHz}, \mathrm{CDCl}_{3}\right) \delta 1.75(2 \mathrm{H}, \mathrm{t}, J=8 \mathrm{~Hz},-\mathrm{SH}), 1.97(6 \mathrm{H}$, s, $\mathrm{CH}_{3^{-}}$at $\left.\mathrm{C}^{13,13}\right), 3.73\left(4 \mathrm{H}, \mathrm{d}, J=8 \mathrm{~Hz},-\mathrm{CH}_{2} \mathrm{SH}\right), 6.28(2 \mathrm{H}, \mathrm{m}$, $\left.H^{14,14^{\prime}}\right), 6.46\left(2 \mathrm{H}, \mathrm{bs}, H^{12,12^{\prime}}\right), 6.47\left(2 \mathrm{H}, \mathrm{m}, H^{11,11^{\prime}}\right), 6.57(2 \mathrm{H}, \mathrm{d}$, $\left.16 \mathrm{~Hz}, H^{9,9}\right), 6.66\left(2 \mathrm{H}, \mathrm{dd}, J=8,2.6 \mathrm{~Hz}, H^{15,15}\right), 6.88(2 \mathrm{H}, \mathrm{m}$, $\left.H^{10,10}\right), 7.26(4 \mathrm{H}, \mathrm{d}, J=8 \mathrm{~Hz}$, Ar-meta- $H), 7.36(4 \mathrm{H}, \mathrm{d}, J=8 \mathrm{~Hz}$, Ar-ortho-H); MS (MALDI-TOF) $\mathrm{m} / \mathrm{z}$ : 456.182 (calcd for $\mathrm{C}_{30} \mathrm{H}_{32} \mathrm{~S}_{2}$ : 456.195); UV/vis (toluene) 330, 347, 426, $451481 \mathrm{~nm}$.

7,7'-Bis(4-acetylthiomethylphenyl)-7,7'-diapocarotene (3a).

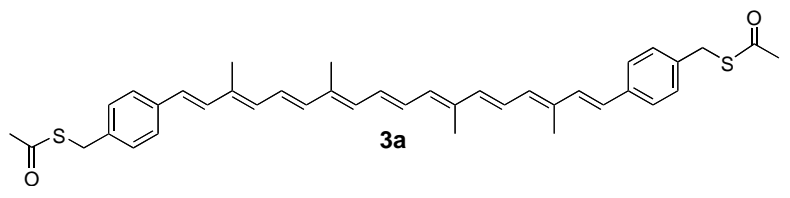

Crocetindial (50 mg, $0.17 \quad \mathrm{mmol})$, 4-acetylthiomethylbenzyltriphenylphosphonium bromide (210 $\mathrm{mg}, 0.403 \mathrm{mmol}$ ), and sodium hydride (60wt \% in mineral oil, 50 $\mathrm{mg}, 1.2 \mathrm{mmol}$ ) were stirred in dry tetrahydrofuran $(50 \mathrm{~mL})$ under $\mathrm{N}_{2}$ at $45^{\circ} \mathrm{C}$ for $24 \mathrm{~h}$. The reaction was quenched with $0.5 \mathrm{M}$ citric acid at $0^{\circ} \mathrm{C}$ and tetrahydrofuran was removed under vacuum. The residue was dissolved in dichloromethane and washed with $0.5 \mathrm{M}$ citric acid and water. After dichloromethane was removed, the residue was chromatographed on a silica gel column (dichloromethane/hexanes, 80/20) to obtain a mixture of cis and trans-isomers. The mixture was dissolved in dichloromethane and adsorbed on a minimum amount of silica gel. After being dried completely, the mixture of the carotene isomers and silica gel was placed on the same volume of dry silica gel in a column and washed with hexane/ethyl acetate (92.5/7.5, $500 \mathrm{~mL}$ ). The compounds remaining on the silica gel were extracted with dichloromethane and the solvents were removed under vacuum to yield an orange residue. The residue was dissolved in dichloromethane and the pure ( $\left.7 E, 7 E^{\prime}\right)$ isomer was precipitated out by adding methanol to the solution. Filtration followed by vacuum drying of the precipitate gave $18 \mathrm{mg}(17 \%)$ of $3 \mathrm{a}:{ }^{1} \mathrm{H}$ NMR (500 MHz, $\left.\mathrm{CDCl}_{3}\right) \delta 1.99\left(6 \mathrm{H}, \mathrm{s}, \mathrm{CH}_{3}-\right.$ at $\left.\mathrm{C}^{13,13}\right), 2.03(6 \mathrm{H}$, s, $\mathrm{CH}_{3}$ - at $\left.\mathrm{C}^{9,9^{\prime}}\right), 4.11\left(4 \mathrm{H}, \mathrm{s},-\mathrm{CH}_{2} \mathrm{~S}-\right), 6.30\left(2 \mathrm{H}, \mathrm{m}, H^{14,14^{\prime}}\right), 6.33$ $\left(2 \mathrm{H}, \mathrm{d}, J=12 \mathrm{~Hz}, H^{10,10^{\prime}}\right), 6.42\left(2 \mathrm{H}, \mathrm{d}, J=16 \mathrm{~Hz}, H^{12,12^{\prime}}\right), 6.55$ $\left(2 \mathrm{H}, \mathrm{d}, J=16 \mathrm{~Hz}, H^{7,7^{\prime}}\right), 6.65\left(2 \mathrm{H}, \mathrm{m}, H^{15,15^{\prime}}\right), 6.68(2 \mathrm{H}, \mathrm{m}$, $\left.H^{11,11}\right), 6.87\left(2 \mathrm{H}, \mathrm{d}, J=16 \mathrm{~Hz}, H^{8,8^{\prime}}\right), 7.23(4 \mathrm{H}, \mathrm{d}, J=8 \mathrm{~Hz}, \mathrm{Ar}-$ meta- $H$ ), 7.35 (4H, d, $J=8 \mathrm{~Hz}$, Ar-ortho- $H$ ); MS (MALDI-TOF) $\mathrm{m} / \mathrm{z}: 620.271$ (calcd for $\mathrm{C}_{40} \mathrm{H}_{44} \mathrm{O}_{2} \mathrm{~S}_{2}: 620.278$ ).

7,7'-Bis(4-thiomethylphenyl)-7,7'-diapocarotene (III).

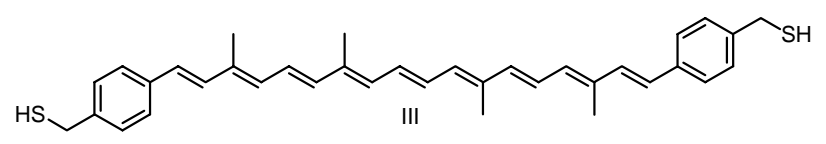

Protected carotene 3a (5 mg, $0.008 \mathrm{mmol}$ ) was dissolved in a mixture of oxygen-free tetrahydrofuran/methanol (40/10, $5 \mathrm{~mL}$ ) and $30 \%$ aqueous ammonia $(1 \mathrm{~mL})$ was added. The mixture was stirred under $\mathrm{N}_{2}$ at room temperature for $48 \mathrm{~h}$. After being acidified with $5 \%$ aqueous L-ascorbic acid, the mixture was diluted with dichloromethane $(25 \mathrm{~mL})$ and washed with water. Flash column chromatography (silica gel, dichloromethane/hexanes, 70/30) gave $2 \mathrm{mg}$ (46 \%) of $3 \mathbf{b}:{ }^{1} \mathrm{H}$ NMR (300 MHz, $\left.\mathrm{CDCl}_{3}\right) \delta 1.75(2 \mathrm{H}, \mathrm{t}, J=8 \mathrm{~Hz},-\mathrm{SH}), 1.99(6 \mathrm{H}$, s, $\mathrm{CH}_{3^{-}}$at $\left.\mathrm{C}^{13,13^{\prime}}\right), 2.04\left(6 \mathrm{H}, \mathrm{s}, \mathrm{CH}_{3^{-}}\right.$at $\left.\mathrm{C}^{9,9^{\prime}}\right), 3.73(4 \mathrm{H}, \mathrm{d}, J=8$ $\left.\mathrm{Hz},-\mathrm{CH}_{2} \mathrm{SH}\right), 6.30\left(2 \mathrm{H}, \mathrm{m}, H^{14,14^{\prime}}\right), 6.33(2 \mathrm{H}, \mathrm{d}, J=11 \mathrm{~Hz}$, $\left.H^{10,10^{\prime}}\right), 6.43\left(2 \mathrm{H}, \mathrm{d}, J=16 \mathrm{~Hz}, H^{12,12^{\prime}}\right), 6.56(2 \mathrm{H}, \mathrm{d}, J=16 \mathrm{~Hz}$, $\left.H^{7,7^{\prime}}\right), 6.65\left(2 \mathrm{H}, \mathrm{m}, H^{15,15^{\prime}}\right), 6.68\left(2 \mathrm{H}, \mathrm{m}, H^{11,11^{\prime}}\right), 6.88(2 \mathrm{H}, \mathrm{d}, J=$ $\left.16 \mathrm{~Hz}, H^{8,8^{\prime}}\right), 7.27(4 \mathrm{H}, \mathrm{d}, J=8 \mathrm{~Hz}$, Ar-meta- $H), 7.38(4 \mathrm{H}, \mathrm{d}, J=$ $8 \mathrm{~Hz}$, Ar-ortho- $H$ ); MS (MALDI-TOF) m/z: 536.245 (calcd for $\mathrm{C}_{36} \mathrm{H}_{40} \mathrm{~S}_{2}$ : 536.257); UV/vis (toluene) 361, 378, 458, 486, $520 \mathrm{~nm}$.

Diethyl-10,10'-diapocarotene-10,10'-dioate (4).

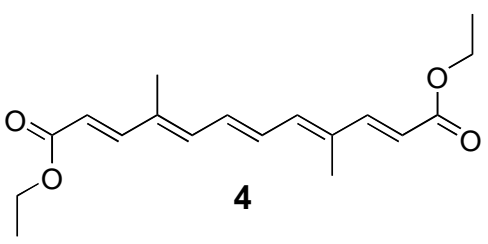

Triethyl phosphonoacetate $(0.45 \mathrm{~mL}, 2.2 \mathrm{mmol})$ and sodium hydride (60 \% in mineral oil, $88 \mathrm{mg}, 2.2 \mathrm{mmol}$ ) were added to 2,7-dimethylocta-2,4,6-triene-1,8-dial (12,12'-diapocarotene12,12'-dial) (328 mg, $2.00 \mathrm{mmol}$ ) dissolved in dry tetrahydrofuran $(17 \mathrm{~mL})$. The mixture was vigorously stirred at room temperature for $30 \mathrm{~min}$. The reaction mixture was diluted with ethyl acetate $(100 \mathrm{~mL})$ and washed with $0.5 \mathrm{M}$ citric acid and water. After ethyl acetate was removed under vacuum, column chromatography (silica gel, dichloromethane/hexanes/ethyl acetate, 70/26/4) of the residue gave $539 \mathrm{mg}$ (88 \%) of diethyl-10,10'-diapocarotene-10,10'dioate 4: ${ }^{1} \mathrm{H}$ NMR $\left(300 \mathrm{MHz}, \mathrm{CDCl}_{3}\right) \delta 1.31(6 \mathrm{H}, \mathrm{t}, J=7 \mathrm{~Hz}$, $\left.\mathrm{CH}_{3} \mathrm{CH}_{2^{-}}\right), 1.95\left(6 \mathrm{H}, \mathrm{s}, \mathrm{CH}_{3^{-}}\right.$at $\left.\mathrm{C}^{13,13}\right), 4.22(4 \mathrm{H}, \mathrm{q}, J=7 \mathrm{~Hz}$, 
$\mathrm{CH}_{3} \mathrm{CH}_{2^{-}}$), $5.94\left(2 \mathrm{H}, \mathrm{d}, J=16 \mathrm{~Hz}, H^{11,11^{\prime}}\right), 6.50\left(2 \mathrm{H}, \mathrm{m}, H^{14,14}\right.$ '), $6.74\left(2 \mathrm{H}\right.$, dd, $\left.J=8 \mathrm{~Hz}, 3 \mathrm{~Hz}, H^{15,15^{\prime}}\right), 7.37(2 \mathrm{H}, \mathrm{d}, J=16 \mathrm{~Hz}$, $\left.H^{12,12^{\prime}}\right)$

10,10'-Diapocarotene-10,10'-dial (5).<smiles>CC(=C/C=C/C=C/C=O)/C=C/C=O</smiles>

5

A $1 \mathrm{M}$ solution of diisobutylaluminum hydride (DIBAL-H) in hexane $(7.8 \mathrm{~mL})$ was added to a suspension of diethyl-10,10'diapocarotene-10,10'-dioate (4) (535 $\mathrm{mg}, 1.76 \mathrm{mmol}$ ) in dry tetrahydrofuran $(15 \mathrm{~mL})$ at $-78^{\circ} \mathrm{C}$. The temperature of the mixture was brought to $-18^{\circ} \mathrm{C}$ in $1 \mathrm{~h}$. At this temperature, the mixture was added to moistened silica gel (10 g, silica gel mixed with $3 \mathrm{~g}$ water), stirred for $30 \mathrm{~min}$. Potassium carbonate (3 g) and magnesium sulfate ( $3 \mathrm{~g}$ ) were added and the mixture was stirred for another $30 \mathrm{~min}$. The mixture was filtered and the filter cake was washed with diethylether. The filtrate was evaporated under vacuum to yield 10,10'-diapocarotene-10,10'-diol which was oxidized without further purification. For the oxidation step, manganese dioxide $(2.42 \mathrm{~g}, 27.8 \mathrm{mmol})$ was added to the diol dissolved in tetrahydrofuran $(20 \mathrm{~mL})$ at $0^{\circ} \mathrm{C}$ and the reaction was monitored by TLC (silica gel, diethyl ether). The mixture was maintained well stirred at room temperature for $2 \mathrm{~h}$. After filtration over Celite 545, the solvent was removed to give 350 mg (92\%) of 10,10'-diapocarotene-10,10'-dial: ${ }^{1} \mathrm{H}$ NMR (300 $\left.\mathrm{MHz}, \mathrm{CDCl}_{3}\right) \delta 2.02\left(6 \mathrm{H}, \mathrm{s}, \mathrm{CH}_{3}-\right.$ at $\left.\mathrm{C}^{13,13}\right), 6.26(2 \mathrm{H}, \mathrm{dd}, J=16$, $\left.8 \mathrm{~Hz}, H^{11,11^{\prime}}\right), 6.64\left(2 \mathrm{H}, \mathrm{m}, H^{14,14^{\prime}}\right), 6.84(2 \mathrm{H}, \mathrm{dd}, J=8,3 \mathrm{~Hz}$, $\left.H^{15,15}\right), 7.33\left(2 \mathrm{H}, \mathrm{d}, J=16 \mathrm{~Hz}, H^{12,12}\right), 9.63(2 \mathrm{H}, \mathrm{dd}, J=8,1.2$ $\mathrm{Hz},-\mathrm{CHO})$.

5,5'-Bis(4-acetylthiomethylphenyl)-5,5'-diapocarotene (6a).

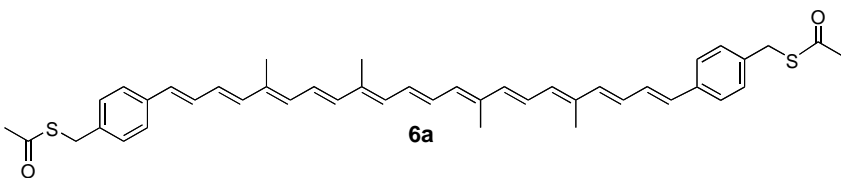

A portion of 4-acetylthiomethylbenzyltriphenylphosphonium bromide (556 mg, $1.26 \mathrm{mmol}$ ) was dissolved in $50 \mathrm{~mL}$ of tetrahydrofuran and placed in an ice bath. To this solution, sodium hydride (54 mg, $1.48 \mathrm{mmol}$ ) was added and the mixture was kept well stirred allowed for one hour. At this time, the ylide solution was added to 6,6'-diapocarotene-6,6'-dial (8) (120 mg, $0.345 \mathrm{mmol}$ ) which had been previously dissolved in tetrahydrofuran. The reaction was allowed to proceed for $18 \mathrm{~h}$. The solution was diluted with dichloromethane and extracted with a $0.5 \mathrm{M}$ citric acid solution. Column chromatography using dichloromethane/hexane (70/30) followed by precipitation of the compound from a dichloromethane solution using methanol yield(4H, s, -CH2S-), 6.28 (2H, m, H14,14'), 6.38 (2H, d, J = 10 Hz, H10,10'), 6.43 (2H, d, J = 16 Hz, H8,8'), 6.46 (2H, d, J = 16 Hz, H5,5'), 6.58 (2H, d, J= 16 Hz, H7,7'), 6.61 (2H, d, J=15.0 Hz, H12), 6.65 (2H, m, H15,15'), 6.70 (2H, m, H11,11'), 6.91 (2H, m, H6,6'), 7.25 (4H, d, J = $8 \mathrm{~Hz}$, Ar-meta-H), 7.35 (4H, d, J = $8 \mathrm{~Hz}$, Ar-ortho-H); MS (MALDI-TOF) m/z: 672.323 (calcd for C44H48O2S2: 672.309). UV/Vis $(\mathrm{CH} 2 \mathrm{Cl} 2)$ 483(sh), 501, 535(sh)ed $22 \mathrm{mg}(9.6 \%)$ of the desired product. 1H NMR (300 $\mathrm{MHz}, \mathrm{CDCl} 3) \delta 1.99$ (12H, s, CH3), 4.11

\section{5,5'-Bis(4-thiomethylphenyl)-5,5'-diapocarotene (IV)}

A portion of 6a (20 mg, $0.029 \mathrm{mmol})$ was dissolved in a $20 \mathrm{~mL}$ of a tetrahydrofuran/methanol (4/1) solution. To this solution 3<smiles>CC(/C=C/C=C/C(C)=C/C=C/C(C)=C/C=C/C=C/c1ccc(CS)cc1)=C\C=C\C=C\C=C\c1ccc(CS)cc1</smiles>
$\mathrm{mL}$ of aqueous ammonia (30\%) were added and the reaction was stirred at room temperature for $24 \mathrm{~h}$. The reaction was quenched by extracting the crude reaction mixture diluted with dichloromethane with a $0.5 \mathrm{M}$ citric acid solution. Evaporation of the solvents yielded $9 \mathrm{mg}$ ( $52 \%$ yield) of the desired compound. MS (MALDI-TOF) m/z: 588.283 (calcd for $\mathrm{C}_{40} \mathrm{H}_{44} \mathrm{~S}_{2}, 588.288$ ): UV/Vis $\left(\mathrm{CH}_{2} \mathrm{Cl}_{2}\right)$ 485(sh), 499, 533(sh).

Diethyl-6,6'-diapocarotene-6,6'-dioate (7).<smiles>CCOC(=O)/C=C/C(C)=C/C=C/C(C)=C/C=C/C=C(C)/C=C/C=C(C)/C=C/C(=O)OCC</smiles>

Triethyl phosphono-acetate (331 $\mathrm{mg}, 1.48 \mathrm{mmol}$ ) was dissolved in $10 \mathrm{~mL}$ of tetrahydrofuran. The solution was cooled in an ice bath, and $55 \mathrm{mg}$ of $\mathrm{NaH}$ (60\% suspension in mineral oil, $1.48 \mathrm{mmol}$ ) were added over $10 \mathrm{~min}$, in order to prevent the reaction from boiling over. This mixture was allowed to stir for 1 hour to ensure the formation of the ylide. Crocetin dial (200 mg, $0.068 \mathrm{mmol}$ ) was dissolved in $50 \mathrm{~mL}$ of tetrahydrofuran. The above ylide was added dropwise and the reaction was allowed to stir until TLC showed the disappearance of the starting dialdehyde and the appearance of the dimethyl ester. The reaction was diluted with dichloromethane and extracted with a dilute citric acid solution. Column chromatography (70/30, dichloromethane/hexane) followed by precipitation of the compound from a dichloromethane solution using methanol yielded $273 \mathrm{mg}$ (92 \% yield) of the desired compound. ${ }^{1} \mathrm{H}$ NMR $\left(300 \mathrm{MHz}, \mathrm{CDCl}_{3}\right) \delta 1.31\left(6 \mathrm{H}, \mathrm{t}, J=7 \mathrm{~Hz}, \mathrm{CH}_{3} \mathrm{CH}_{2^{-}}\right), 1.94(6 \mathrm{H}$, s, $\mathrm{CH}_{3^{-}}$at $\left.\mathrm{C}^{13,13^{\prime}}\right), 1.96\left(6 \mathrm{H}, \mathrm{s}, \mathrm{CH}_{3^{-}}\right.$at $\left.\mathrm{C}^{9,9^{\prime}}\right), 4.25(4 \mathrm{H}, \mathrm{q}, J=7$ $\left.\mathrm{Hz}, \mathrm{CH}_{3} \mathrm{CH}_{2^{-}}\right), 5.90\left(2 \mathrm{H}, \mathrm{d}, J=16 \mathrm{~Hz}, H^{7}, 7^{\prime}\right), 6.30\left(2 \mathrm{H}, \mathrm{m}, H^{14,14^{\prime}}\right)$, $6.50\left(2 \mathrm{H}, \mathrm{d}, J=13 \mathrm{~Hz}, H^{10,10^{\prime}}\right), 6.58\left(2 \mathrm{H}, \mathrm{d}, J=15 \mathrm{~Hz}, H^{12,12^{\prime}}\right)$, $6.62\left(2 \mathrm{H}, \mathrm{m}, H^{11,11^{\prime}}\right), 6.70\left(2 \mathrm{H}, \mathrm{m}, H^{15,15^{\prime \prime}}\right), 7.40(2 \mathrm{H}, \mathrm{d}, J=16 \mathrm{~Hz}$, $H^{8,8^{\prime}}$ ). MS (MALDI-TOF) m/z: 436.246 (calcd for $\mathrm{C}_{28} \mathrm{H}_{36} \mathrm{O}_{4}$, 436.261).

6,6'-Diapocarotene-6,6'-dial (8).

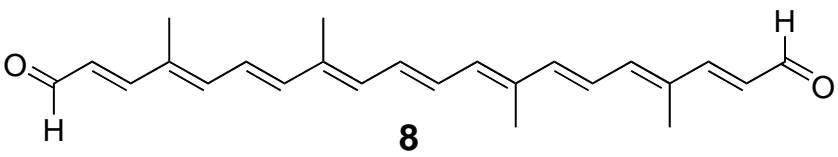

Diethyl-6,6'-diapocarotene-6,6'-dioate (7) (273 mg, 0.63 mmol) was dissolved in $50 \mathrm{~mL}$ tetrahydrofuran and the solution was cooled in an ice bath. Once the solution was cooled, diisobutylaluminum hydride (DIBAL-H) $(2.5 \mathrm{~mL}, 2.5 \mathrm{mmol})$ was added dropwise and the reaction was allowed to stir while being monitored by TLC. After $2 \mathrm{~h}$ an additional $2 \mathrm{~mL}(2 \mathrm{mmol})$ of DIBAL-H were added and the reaction was stopped after an additional $3 \mathrm{~h}$. The reaction was quenched by extraction with water and dichloromethane, and dried under high pressure to yield 6,6'-diapocarotene-6,6'-diol. (MALDI-TOF) m/z: 352.211 (calcd for $\mathrm{C}_{24} \mathrm{H}_{32} \mathrm{O}_{2}, 352.240$ ). This compound was oxidized without further purification by dissolving it in acetone $(40 \mathrm{~mL})$ and 
adding $\mathrm{MnO}_{2}$ (1.5 g, $18 \mathrm{mmol}$ ). The solution was stirred under $\mathrm{N}_{2}$ for $12 \mathrm{~h}$. Filtration through Celite 545, and removal of the solvent afforded $120 \mathrm{mg}$ (55\% yield) of the desired compound. (MALDITOF) m/z: 348.204 (calcd for $\mathrm{C}_{24} \mathrm{H}_{28} \mathrm{O}_{2}$, 348.208).

References.

(1) Ramachandran, G. K.; Tomfohr, J. K.; Li, J.; Sankey, O. F.; Zarate, X.; Primak, A.; Terazono, Y.; Moore, T. A.; Moore, A. L.; Gust, D.; Nagahara, L. A.; Lindsay, S. M. J. Phys. Chem. B 2003, 107, 6162-6169.

(2) Makin, S. M.; Telegina, N. I. J. Gen. Chem. USSR 1962, 32, 1082-1087.

(3) Van Wijk, A. A. C.; Lugtenburg, J. Eur. J. Org. Chem. 2002, 4217-4221.

(4) Brown, B. O.; Weedon, B. C. L. Finn. Chem. Lett. 1984, 102-111. 